\title{
無潤滑滑り接触におけるジルコニアの摩擦摩耗機構
}

\author{
大越将洋・藤田光広・広中清一郎 \\ 東京工業大学工学部無機材料工学科, 152 東京都目黒区大岡山 2-12-1
}

\section{Friction and Wear Mechanism of Zirconia in Unlubricated Sliding Contact}

Masahiro OHGOSHI, Mitsuhiro FUJITA and Seiichiro HIRONAKA

Department of Inorganic Materials, Faculty of Engineering, Tokyo Institute of Technology, 2-12-1, O-okayama, Meguro-ku, Tokyo

The friction and wear properties of self-mated zirconia $\left(\mathrm{ZrO}_{2}\right)$ in unlubricated sliding contact were investigated by using a pin/disk friction machine. From the obtatined results and the morphologies of frictional surfaces observed by SEM and particle size distribution of wear particles, the friction and wear mechanism of $\mathrm{ZrO}_{2}$ pin slide against $\mathrm{ZrO}_{2}$ disk was discussed. In this system, the average friction coefficient was almost independent of the load applied, but the wear amount increased with an increase of the load. The wear particle sizes became larger with increasing sliding time and load applied. It is found that the friction and wear mechanism of $\mathrm{ZrO}_{2}$ is dominated with the formation, delamination and fracture of surface film transferred on frictional surfaces by friction and adhesion, and that they are influenced by friction heat and the load applied.

[Received December 27, 1995; Accepted March 15, 1996]

Key-words : Zirconia, Friction, Wear, Wear particle

\section{1. 緒言}

セラミックスは高硬度, 耐熱性, 断熱性, 耐摩耗性などの優 れた特性を有することから，トライボ材料としてのセラミック スの摩擦摩耗に関する基礎的研究は多くなされており，荷重や 滑り速度などの機械的条件や温度，摩擦環境の観点から，その 摩擦摩耗機構は明らかにされつつある。一方, 摩擦摩耗に伴う 摩耗粉の生成及びその摩擦摩耗に対する影響を主とした研究は 比較的少ない，金属の摩擦摩耗においては，シビア摩耗からマ イルド摩耗への遷移における摩耗粉の役割 1 , , 各種金属間の摩 擦摩耗への摩耗粉の影響2), またフェログラフィーによる摩擦 条件と摩耗粉の粒度分布との関係3) や潤滑管理上のフェログラ フィーによる摩耗粉の生成の解析 $\left.{ }^{4}\right)$ な゙があり, 摩擦環境 ${ }^{2}$ や 摩擦条件 2 (2) (3)によって摩耗粉の役割や摩耗粉粒度分布が異なる ことが報告されている，セラミックスに関しては， $\mathrm{SiC}$ 系セラ ミックスの摩耗粉としての発塵特性についてクリーン環境の点 か $5^{5)}, \mathrm{SiC}$ の摩擦摩耗への介在摩耗粉の影響6), SIALON や $\mathrm{Al}_{2} \mathrm{O}_{3}$ などの滑り摩擦における摩耗粉の機械的作用7)などが研 究されて抢り, 摩擦摩耗に伴う摩耗粉の生成はセラミックスの 摩擦摩耗特性に大きな影響をもつことが明らかにされている.

本研究では, $\mathrm{ZrO}_{2} / \mathrm{ZrO}_{2}$ 系の無潤滑滑り摩擦における摩擦 摩耗特性をピン/ディスク摩擦試験機により測定し, 得られた 結果と摩擦表面の走查型電子顕微鏡（SEM）観察によるモル ホロジー及びレーザー分散型マイクロトラック粒度分析計によ る摩耗粉の粒度分布から， $\mathrm{ZrO}_{2}$ の摩擦摩耗機構を検討した。

\section{2. 実験方法}

\section{2. $1 \mathrm{ZrO}_{2}$ セラミックス試料}

試料としてのジルコニア $\left(\mathrm{ZrO}_{2}\right)$ は純度 $99.6 \%$, 平均粒径 $0.09 \mu \mathrm{m}$ の原料粉末を CIP で成形したものを最高温度 1400 $1500^{\circ} \mathrm{C}$ (大気中）で焼結し，円柱ピン（直径： $4 \mathrm{~mm}$, 長さ： $10 \mathrm{~mm}$ ) 及びディスク（外径 : $50 \mathrm{~mm}$, 内径 : $10 \mathrm{~mm}$, 厚さ： $7 \mathrm{~mm}$ ）に研削，研磨したものを試験片とした. $\mathrm{ZrO}_{2}$ の物性は 表 1 に示す。試験片の表面粗さは $R_{\mathrm{a}}: 0.2975 \mu \mathrm{m}, R_{\mathrm{MAX}}$ : $1.639 \mu \mathrm{m}$ （電子線三次元粗さ装置，エリオニクス製）であっ た.
Table 1. Physical Properties of $\mathrm{ZrO}_{2}$

\begin{tabular}{|l|l|}
\hline Bulk Density & $6.0 \mathrm{~g} / \mathrm{cm}^{3}$ \\
\hline Vickers Hardness (HV $)$ & $12.3 \mathrm{GPa}$ \\
\hline Flexural Strength & $850 \mathrm{MPa}$ \\
\hline Young's Modulus & $206 \mathrm{GPa}$ \\
\hline Poisson' s Ratio (v) & 0.31 \\
\hline Fracture Toughness ( $\left.\mathrm{K}_{\mathrm{I}} \mathrm{C}\right)$ & $6.7 \mathrm{MPa} \cdot \mathrm{m}^{1 / 2}$ \\
\hline Thermal Conductivity & $4 \mathrm{~W} / \mathrm{mK}^{1}$ \\
\hline $\begin{array}{l}\text { Linear Thermal Expansion } \\
\text { Coefficient (40-800 }\end{array}$ & $\left.11.0 \times 10^{-6}\right)$ \\
\hline
\end{tabular}

\section{2 摩擦摩耗試験}

摩擦摩耗試験はピン/ディスク摩擦試験機により8), 滑り速 度 : $46.6 \mathrm{~cm} / \mathrm{s}(222 \mathrm{rpm})$, 荷重 : $4.9 \sim 19.6 \mathrm{~N}$, 摩擦時間は 摩擦測定 : $5 \mathrm{~h}$, 摩耗測定 : $20 \mathrm{~h}$, 室温, 相対湿度 : $20 \sim 45 \%$, 空気中で行った。摩耗量は摩擦前後の重量変化より求めた。摩 擦係数の経時変化及び荷重依存性, 比摩耗量の荷重依存性, 摩 耗粉粒径の経時変化及び荷重依存性を検討した．試験片はアセ トン及びトルエンによりそれぞれ交互に10 min ずつ超音波洗 浄し, 乾燥剤入りデシケーター中に $48 \mathrm{~h}$ 以上保管したものを使 用した。

\section{3 摩耗粉の粒度測定}

摩耗粉の粒度はレーザー分散型マイクロトラック粒度分析計 により測定した。採取した摩耗粉は，分散剤としてへキサメタ リン酸ナトリウムを用い，水中に超音波により分散させた。得 
られた結果より摩耗粉の粒度分布（粒子の個数の割合）の経時 変化及び荷重依存性について検討した.

\section{4 摩擦表面のモルホロジー}

試験後の摩擦表面のモルホロジーは SEM により検討し，摩 擦摩耗の測定結果と合わせて $\mathrm{ZrO}_{2}$ の摩擦摩耗機構を考察し た.

\section{3. 実験結果及び考察}

\section{1 摩擦摩耗特性と摩擦面のモルホロジー}

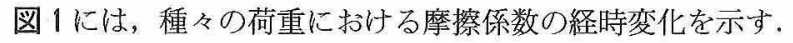
摩擦時間約 $3 \mathrm{~h}$ までの摩擦前期においては, 摩擦係数は高荷重 よりも低荷重に拈ける方が大きいが，それ以後になると，この 傾向は逆転した，摩擦前期の低荷重においては，摩耗粉粒径や 摩耗量はそれほど大きくなく，表面移着膜を形成する摩擦面間 の凝着に起因して摩擦係数は大きくなったものと考えられる。

しかし，時間経過とともにこの表面移着膜が摩擦面全体を滑ら かに覆うようになり，摩擦係数はむしろ低下する傾向を示し た。これに対して高荷重になるにつれて，この表面移着膜は摩 耗粉として剥離又は破壊され，摩擦時間の経過とともに摩擦面 間に多く介在するようになり，これが高摩擦係数に反映するも のと考えられる.

摩擦係数及び比摩耗量（単位滑り距離当たり, また単位荷重 当たりの摩耗体積, $\mathrm{mm}^{3} \cdot \mathrm{N}^{-1} \cdot \mathrm{m}^{-1}$ ) の荷重依存性を図 2 に示

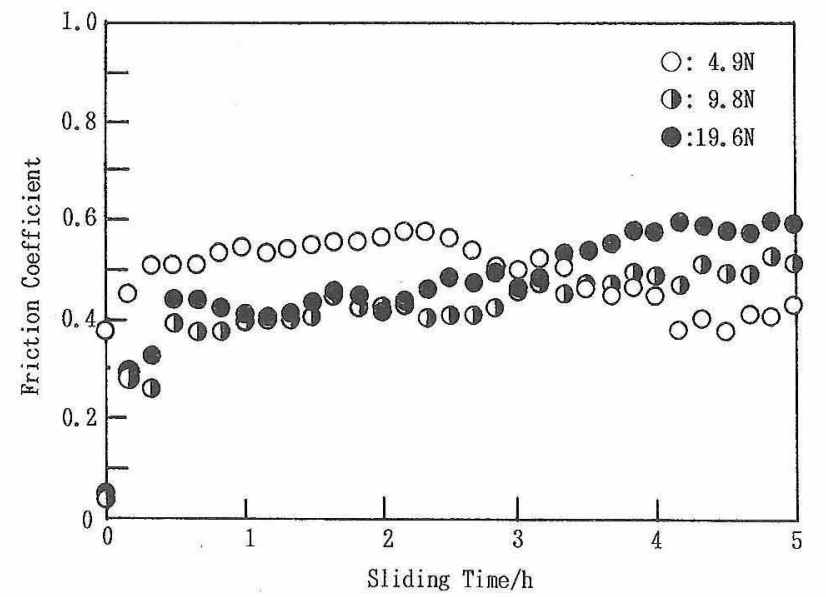

Fig. 1. Friction coefficient as a function of sliding time under various loads.

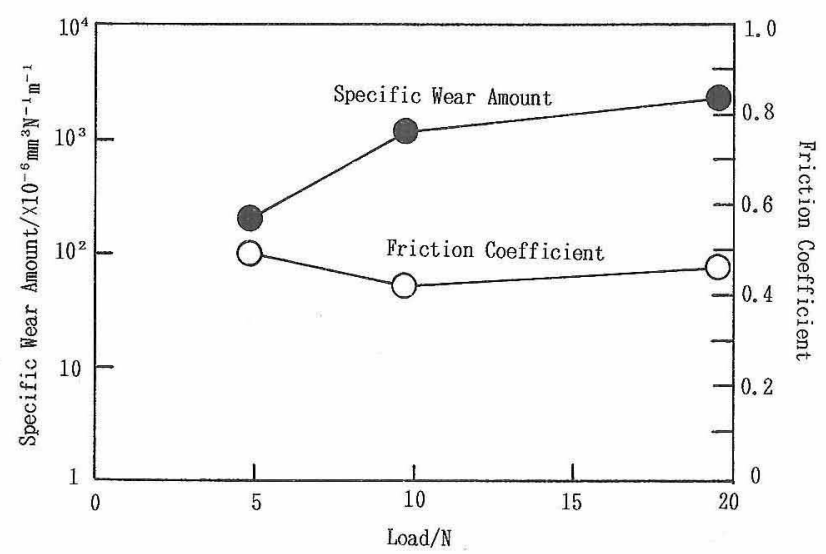

Fig. 2. The relation between specific wear amount and friction coefficient and load.
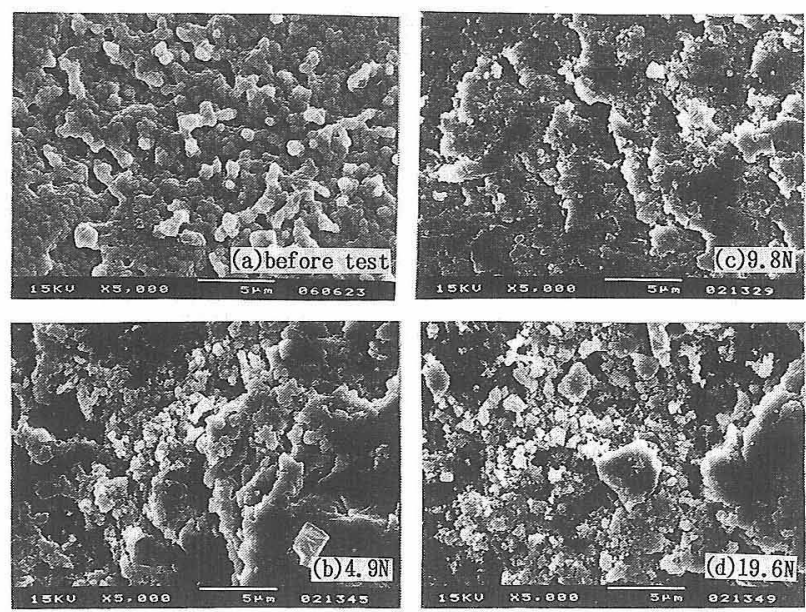

Fig. 3. Scanning electron micrographs of frictional surface of pins.

す。摩擦係数は摩擦時間 $1 \sim 5 h$ の平均值を採用した。本実験 条件範囲内では, 平均摩擦係数は荷重依存性は低く, 約 0.4 0.5 程度であった. 比摩耗量は高荷重になるほど増大し, 19.6 $\mathrm{N}$ の比摩耗量は $4.9 \mathrm{~N}$ における比摩耗量より 1 けた大きい值を 示した.

$\mathrm{ZrO}_{2} / \mathrm{ZrO}_{2}$ 系の滑り摩擦において, 加藤と林 ${ }^{9}$ は摩耗形態を 分類しているが, 本実験の比摩耗量と摩擦表面のSEM 観察 (図 3， $\mathrm{ZrO}_{2}$ ピン表面）から，この系に朽ける摩擦摩耗機構は 次の上うに考察される， $\mathrm{ZrO}_{2}$ の摩耗機構は相手面との凝着及 び移着による表面膜の形成と剝離及び摩擦剪断による表面膜の 破壊が支配的である. 図 3 (b)に示すように，低荷重では表面 移着膜とこの表面膜の一部加らの小さい摩耗粉の脱落が起こ り, 上り高荷重になると（図 3 (d)), 表面移着膜の剥離と破 壊が起こりやすくなり, より大さな摩耗粉が生成されるむのと 考えられる。

\section{2 摩耗粉の粒度分布}

$\mathrm{ZrO}_{2} / \mathrm{ZrO}_{2}$ の無潤滑滑り摩擦の荷重 $4.9 \mathrm{~N}$ 及じ $9.8 \mathrm{~N}$ におけ 万各摩擦時間区間に生成される摩耗粉の粒度分布（粒子の個数 の割合）の経時変化をそれぞれ図４と図５に示す。両荷重のい ずれの摩擦時間区間においても，0.34 $\mu \mathrm{m}$ 前後の粒径をむ摩 耗粉の頻度が最も高い割合を示した。摩擦時間区間が長時間側 へ移行するにつれて $0.34 \mu \mathrm{m}$ のピークは小さくなり，次第に大

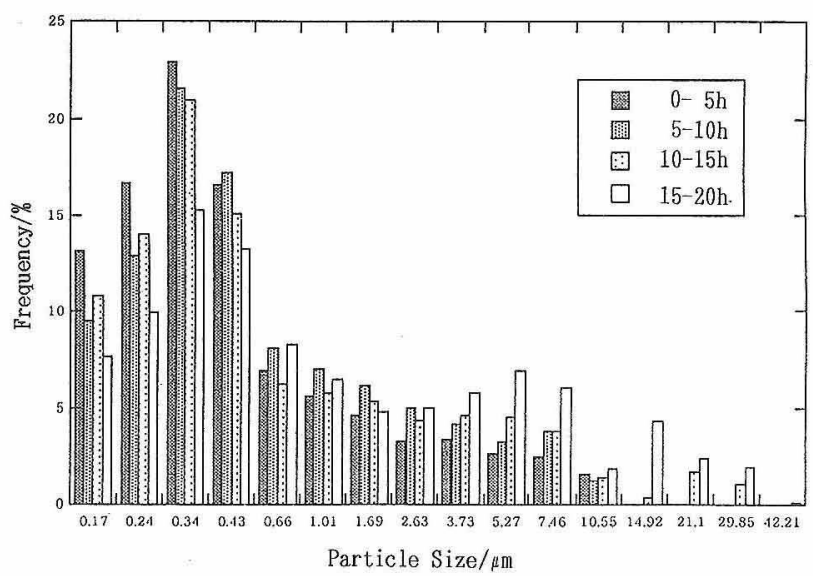

Fig. 4. Particle size distribution of wear particles obtained under $4.9 \mathrm{~N}$. 


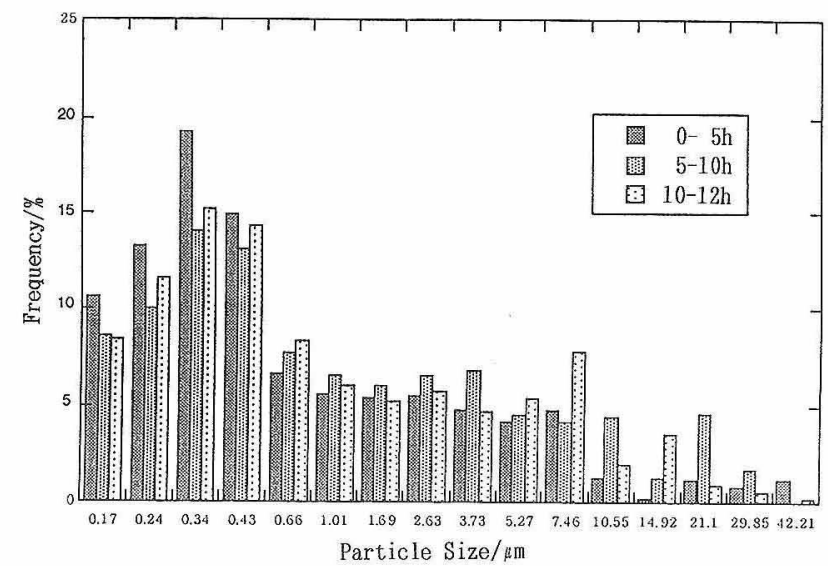

Fig. 5. Particle size distribution of wear particles obtained under $9.8 \mathrm{~N}$.

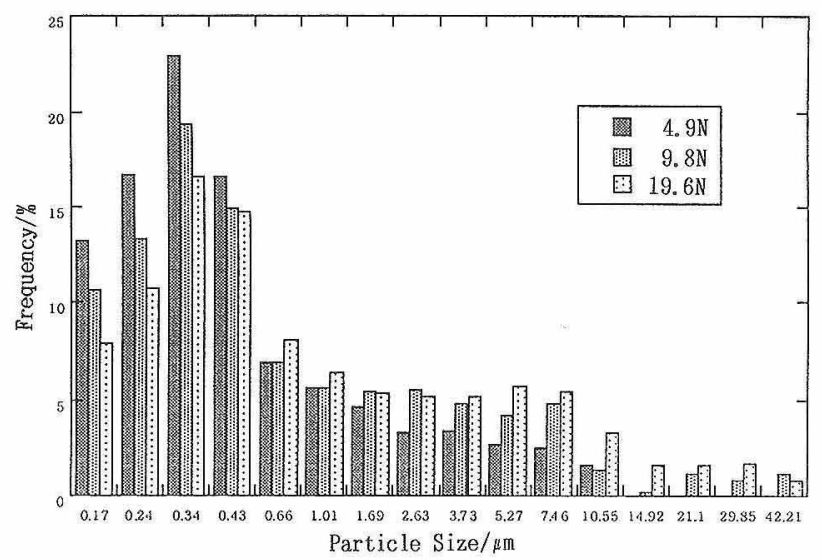

Fig. 6. The effect of load on particle size distribuiton of wear particles.

きな摩耗粉の割合が大きくなる傾向を示した。

図 6 は，試験開始から5h 経過後までの摩耗粉の粒度分布の 荷重依存性を示す，いずれの荷重においても，0.34 $\mu \mathrm{m}$ 前後の 粒径の摩耗粉の頻度が最も高い割合を示した.屯た高荷重にな

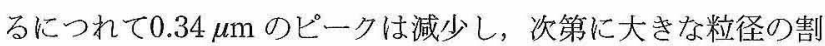
合が大きくなっている.

$0.34 \mu \mathrm{m}$ 粒子の最大ピークの出現は現段階ではいまだ明らか
にされていないが，未摩擦面のSEM 観察から，焼結粒の平均 粒径はこの付近に存在するものと推察され，この付近の粒径の 粒子が多く摩耗粉として生成されるものと考えられる. また摩 擦時間経過及び荷重の増加とともに，より大きな摩耗粉生成へ と移行することは, 表面移着膜の剝離や破壊によって起こるも のと推察される。 あた摩擦時間経過と荷重の増大とともに, 摩 擦熱の発生と蓄熱が増大し, 摩擦応力による表面マイクロク ラックの内部への伝ぱは起こりやすくなり，これらが表面移着 膜の剝離や破壊を起こし，より大きな摩耗粉の生成への起因に なるものと考えられる。

\section{4. 結 論}

ピン/ディスク摩擦試験による $\mathrm{ZrO}_{2}$ 同士の無潤滑滑り摩擦 に抢ける摩擦摩耗特性と摩耗粉の生成機構についての検討結果 から，次のように結論される。

（1）平均摩擦係数の荷重依存性は小さいが，摩耗量满重 の増大とともに増加する傾向を示した。

（2）摩耗粉は，摩擦時間の経過とをむに，また荷重の増大 とともにより大きな摩耗粉が生成される傾向が得られた。

(3) $\mathrm{ZrO}_{2}$ の摩擦摩耗機構は, 摩擦間面の凝着による表面移 着膜の形成と剥離及びこの表面移着膜の摩擦剪断による破壊が 支配的で, 負荷条件や摩摖熱の影響を受けることが明らかと なった。

謝 辞 摩耗粉の粒度分布測定にご協力頂いた東京工業大学 工学部無機材料工学科の岡田 清教授ならびに龟島欣一助手に感 謝致します。また摩擦表面のSEM 写真及び表面粗さの測定にご 協力頂きました株式会社エリオニクスヘ深く感謝致します。

\section{文 献}

1) 平塚健一, 日本機械学会論文集, 58-C, 3362 (1992).

2) 桑原改造, 升本秀治, 潤滑, 25, 126 (1980).

3）久村健一, 木村好次, 中野 健, 日本トライボロジ一学会卜 ライボロジー会議予稿集 (1995-5) p. 63.

4) 野呂瀬 進, 佐藤明史, 笹田 直, 潤滑, 28, 685 (1983),

5） 三宅正二郎, 北野雅之, 山元賢二, トライボロシスト，40, 153 (1995).

6）楊 林, 門田光央, 橋本正明, 山本雄二, 日本トライボロ ジー学会トライボロジー会議予稿集 (1994-10) p. 269.

7) J. Denape and J. Lamon, J. Mater. Sci., 25, 3592 (1990).

8) 大越将洋, 藤田光広, 広中清一郎, 日本トライボロジー学会 トライボロジー会議予稿集 (1995-5) p. 589.

9）加藤康司, 林 慎之, 日本トライボロジー学会トライボロ ジー会議予稿集 $(1992-10)$ p. 219. 